\title{
MIR27A Gene
}

National Cancer Institute

\section{Source}

National Cancer Institute. MIR27A Gene. NCI Thesaurus. Code C80746.

This gene is involved in the regulation of gene expression and plays a role in the development of hepatocellular, gastric and breast carcinomas. 